\title{
Medical Professionalism: Can It, Should It Survive?
}

Much is being written these days about the deprofessionalization of medicine. ${ }^{1}$ This term generally connotes deep concern about the loss of that special dedication to competence, service, and other-thanself-interest that have been associated with the best physicians for so long. In today's terms, deprofessionalization is usually equated with the drastic transformation of physicians in the last several decades into union-oriented corporate employees, on the one hand, and entrepreneurs, investors, and corporate executives, on the other.

Millennial anxieties notwithstanding, this phenomenon is not new. In its history, medicine has witnessed recurrent cycles of moral confusion - of doubts about whether there is something special about the activity of medicine that imposes a higher standard of moral integrity on its practitioners. When a profession is deprofessionalized, it denies those higher standards and accommodates to the dominant climate of its time. Each time this conflict has arisen in the past, it has eventuated in a new infusion of moral sensitivity. Such was true when the Hippocratic physicians distanced themselves from the mass of their contemporaries by a set of moral precepts as their source of identity; it was true of the American Medical Association's first code of ethics. ${ }^{2}$ That code, itself, was copied from Thomas Percival's Code of 1803 , which was written to end another ethical turmoil in the staff of the Manchester Infirmary.

Whether today's confusion will result in another infusion of ethical concern into the profession, whether it will permanently divide the profession, or whether the idea of professional ethics should now be abandoned as outmoded is problematic. To box the compass of these questions, it is essential to define professionalism, itself, then to look at the features of the present cycle to determine which are common to past cycles and which are unique.

Submitted 24 December 1999.

From the Center for Clinical Bioethics, Georgetown University Medical Center, Washington DC. Address reprint requests to Edmund D. Pellegrino, MD, Center for Clinical Bioethics, Georgetown University Medical Center, 4000 Reservoir Road, NW, \#D-238, Washington DC 20007.
Professionalism and profession are words with elastic meanings that should be separated from each other at the outset.

The dominant conception is sociological. On that view, a profession is any group sharing a special body of knowledge, standards of education and practice, professional associations, and an ethical framework based in a social contract that permits a high degree of self-regulation. ${ }^{3}$ On that view, ethics is an important descriptor for a profession, but ethics is not its essential and indispensable defining feature.

Another view of a profession links it to an ethical ideal without which it cannot exist. That ideal focuses on some degree of effacement of self-interest when it is required by the good of the person seeking assistance. This conception is rooted in the etymology of the word profession, which means "a declaration, promise, or commitment publicly announced." ${ }^{4}$ That promise is made in every clinical encounter when the physician offers to help those who need his or her special knowledge. That promise entails competence and putting that competence at the service of the patient, even when it means some degree of sacrifice on the part of the physician. $^{5}$

Both of those visions are distinct from the distorted notion of professionalism, which denotes a self-protective, self-interest-promoting, guild spirit embodied in an organization protective of privileges, much as a labor union might see them. Deprofessionalization of this corrupted form of profession would not be lamented.

The reality of cycles of moral confusion must not obscure the specific dimensions of the present recurrence - some of which are unique; some not. What are not unique are the temptations of selfinterest, power, prestige, pride, profit, and privilege that beset all humans, in all ages. Some are able to resist for moral reasons, and others are not. Venality, character deficiencies, irresponsibility, and greed are not peculiar to any period.

In our times, however, there are two sources of unique conflict - one societal and one ethical.

Some of the social factors stand out as especially pertinent in our times. First is the defection of 
physicians, themselves, from medical ethics - from Medicare fraud to medical error to conflicts of interest in research. Then, there is the commodification of health care as a product like any other, left to the ethos of the marketplace, to competition, commercialization, and profit making. Added to those is the shift of professional lifestyles to a greater emphasis on free time, leisure activity, and a 9-to-5 day. Most important, perhaps, is the legitimization of profit, competition, and self-interest inherent in a free-market economy. In our times, these have even become moral imperatives, thus badly confusing economics and ethics.

The end result is a physician who is an employee whose loyalties are divided between organization and patient, and whose self-interests are pitted against the patient to curb costs or make profits. Individual patients see physicians as interchangeable, of no special importance as individuals. Physicians are urged to practice social, rather than individual patient, ethics. Their professional worth is measured in productivity. They are not held to moral standards higher than those of the general society in which they live.

Also unique to our times is the erosion of the foundations of professional ethics, which might have energized a mitigation or reversal of those current trends to deprofessionalization. The Hippocratic Oath has been denied historical credibility; each of its precepts is challenged, and its content is negotiable or understood simply as a changeable construct of societal mores. Underlying those challenges is the pervasive moral skepticism that denies the validity of any stable moral truth and even the capacity of reason to apprehend such truth even if it were to exist. All of this is exacerbated by cultural diversity, which induces a strong tendency to moral relativism.

Clearly, the confluence of those forces makes the current cycle of moral confusion and deprofessionalization much more difficult to reverse than previous cycles. Indeed, critics of medicine - some physicians among them - say that, ultimately, the end of ethics is at hand. On that view there is nothing special about medicine. It is an occupation like any other. The marketplace is the proper venue for health care. Patients will fare better if competition is unfettered and profit is encouraged. Moralists and ethicists are unrealistic to demand more of physicians than others in our society. On that view, also, reprofessionalization or reconfirming ethics would be a retrogressive step toward a species of idealism that has never worked anyway.

To predict how the current cycle of moral confusion will end requires a degree of confidence only the disorientation of millennial hyperpyrexia could induce. Clearly, some things will make reconstitution more difficult than in times past. First is that the opposing positions are inherently irreconcilable. As a result, accommodation or compromise amounts to ethical capitulation. Moreover, even if profit is not the motive, some physicians prefer the life of a proletarian with less personal commitment to their work. Finally, the legitimization and exaltation of the profit motive has an inherent appeal to the American spirit of individualism and free enterprise. It also justifies the entrepreneurialism on the one hand and the compromises on the other.

The difficulties notwithstanding, it is not likely that professional ethics is at its end. There are, and will be, physicians who, like the Hippocratics, will appreciate that theirs is a special species of human activity. They will recognize the moral foundations of professionalization in the vulnerability of sick persons, in the necessity of trusting the physician and relying on his or her character, in the physician's invitation to trust, and in the sick person's moral claim on the physician's competence and on the use of that competence in the patient's best interests rather than the physician's own interests.

I expect, therefore, a repetition of the historic cycle of deprofessionalization and reprofessionalization characteristic of periods of moral confusion. To be sure, as in Hippocratic times and as at the time of the first AMA code in 1847, there will be physicians unresponsive to the central ethical call of the care for the sick. Perhaps they will be the majority in the next century. But we can hope that a new group of neo-Hippocratics will also emerge, influential enough to restore the moral status and integrity of our ancient profession - not to regain prerogatives for themselves, but to assure that the primacy of the welfare of their patients will be preserved. Only when medicine is a moral enterprise is that possible.

The greatest danger is probably not taking one side or the other, but failing to take either side. In today's climate of easy tolerance of moral diversity, choosing among disputed positions is anathema. 
This might work in politics, but it is inadmissible in morality, where not to decide is to be complicit in injustice and wrongdoing.

\section{Edmund D. Pellegrino, MD Washington, DC}

\section{References}

1. Wynia MK, Latham SR, Kao AC, Berg JW, Emanuel LL. Medical professionalism in society. N Engl J Med 1999;341:1612-16.

2. Pellegrino ED. One hundred fifty years later: The moral status and relevance of the AMA Code of Ethics. In: Baker RB, Caplan AL, Emanuel LL,
Latham SR, editors. The American medical ethics revolution: How the AMA's code of ethics has transformed physicians' relationships to patients, professionals, and society. Baltimore: Johns Hopkins University Press, 1999:107-23.

3. Parsons T. The professions and social structures. Social Forces 1939;17:457-67.

4. Onions CT, editor. The Oxford dictionary of English etymology. Oxford: Clarendon Press, 1966.

5. Pellegrino ED. The healing relationship: The architectonics of clinical medicine. In: Shelp E, editor. The clinical encounter: the moral fabric of the patient-physician relationship. $4^{\text {th }}$ ed. Dordrecht, Boston: Reidel, 1983: 153-72. 